\title{
Family Planning: An Important Issue In The Light Of Islamic Teaching
}

\author{
Shahnaz Ghazi \\ Department of Qur'an \& Sunnah \\ University of Karachi
}

\begin{abstract}
The aim of this research is to facilitate the understanding of family planning. The researcher also examine the issue with reference to controversy and the necessity to understand the problem and its solution is also discussed in detail. The major objective of the paper is to develop a good understanding of family planning in the light of Islamic teaching. This research paper also explores the role of different ministries and religious leaders in this regard.

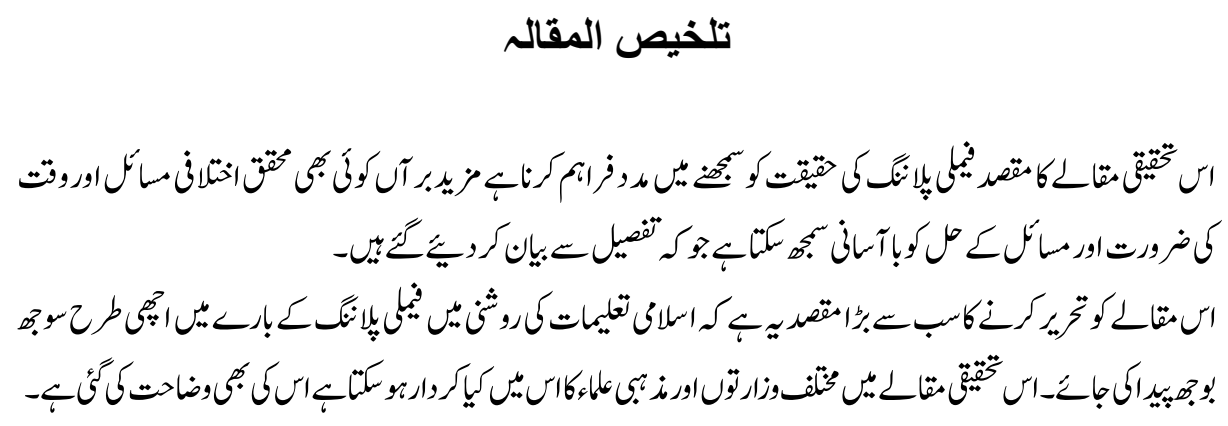

Islam is not only a religion but also a complete code of life.

"Nothing fresh or dry, but is written in a clear record" (Al- Quran, 6:59)

Islam has provided rules and regulations regarding all aspects of life. It prescribes moral and social principles for regulating our individual and group behaviors. We must understand the teachings of Islam and Qur'an demands:

"Do they not then think deeply in the Qur'an, or are their hearts locked up (From understating it)" (Al-Quran, 47:24)

Allah has given more knowledge to man than the angels and he is the representative of Allah on earth and called "Ashraf-ul-Makhlooqat" The Best Creature. Having this great status we must have a complete comprehension of Qur'an and Sunn'ah to know the actual cause of His creation i.e.

"And I (Allah) created not the Jinn and Mankind except that they should worship me (alone)" (Al- Quran, 51:56). 
And this worshiping of Allah is of two types. One is called "Huqooq Allah" (Rights of Allah) and the second one is called "Huqooq-al-Ibad" (Rights of Human Beings). Every person should know their rights as well as their duties because human is a living, rational and cultured being; their life depends on cooperation of other human beings. A person cannot attain the necessities of life without being civilized. He needs a code of life, which will grant him peace tranquillity and security. Every person strives to discover the ways and means to mould his patter of life in a civilized way. To carve out his way, Islam sets certain limitations as enshrined.

"These are the limits ordained by Allah so do not transgress them and however transgresses the limits ordained by Allah, then such are the wrong doers" (Al-Quran, 2:229)

Acting thus, every person should know about his limitations. If we adopt unlawful ways, we will be penalized, so we have to be careful in every area of our life. In this world we interact a million of things. Among the things we use, there are many that Allah and Holy Prophet have made lawful and have permitted us clearly to use them. Similarly some actions and some things have been very clearly made unlawful which are forbidden. So when a person embraces Islam waiving his freedom of choice and subordinating himself to the will of Allah, he should also believe in Allah and His Prophet (P.B.U.H.). When they enjoin us to some actions, they are certainly for our benefit and likewise when they forbid us something it must contain some harm to us.

According to the teaching of Islam, a human is supposed to approach the problems and he needs to find the solution. Today's challenging issue is family planning because of Pakistan's growing rate of population over the last few decades. Although Government and different NGOs are already playing an active role for promoting family planning program, However, from the very beginning this program has been surviving under threat and made controversial among public, politicians and religious leaders. People feel that it is in conflict with Islamic rules.

There are so many reasons for the failure of Family Planning Program in Pakistan.

\section{Misconceptions}

Majority of the people think that it is a western idea for decreasing the Muslim's population. Mostly people belong to different school of thoughts and follow their specific believes. However religious scholars have higher knowledge of family planning compared to a cleric.

The influence of Imams of mosques on the general public is more than that of scholars because of their close and direct contact with the people. It has been observed that some 
of the Imam's background is not very strong. The education of Imams of mosques are informal, their views are inconsistent and emotional Hence, they oppose this program. The result is that Pakistan is still far behind in controlling its population growth rate to the desired level.

In the light of Quran and Sunnah there is a need to involve religious leaders in the advocacy for the program. Invite them to discuss population issues on print media and electronic media so an effective and better campaign is needed. Recently media is striving for the cause but unfortunately good results are not achieved yet. Since the last two years so many medical practitioners, religious scholars and academic personals need to work together and they all need to support the issue. In Quran and Sunnah there are certain prohibitions and certain liberties, and this particular issue of family planning is neither prohibited nor permitted. We have to derive its solution through understanding of religion which is known as Tafaquh - Fid - Deen. We need to understand the true spirit of Islamic rules. We need to learn and understand the Qur'anic meaning, the real teaching of Islam have so much easiness for the pople.

\section{Qur'an Says:}

"And let not your hand be tied (like a miser) to your neither neck nor stretch it forth to its utmost reach (like a spend thrift), so that you become blame worthy and in severe poverty". (Al- Quran, 17:29)

Instruction about moderation and balance are given in this verse. Poverty is caused by our mismanagement of wealth, hence balance is advocated. There is an advice hidden in this verse that plan your family budget according to your earnings, if you mismanage your budget, you will commit disobedience to Allah and will be denied the fruits of secured and peaceful life. If we do not plan our family, we will likely to suffer. It will increase the probability of poverty. Although Allah has taken the responsibility of providing food to all creatures while living in the world inside the stone, but it is our responsibility to strive and search for food. Our struggle for the search of food is limited to the resources which are scarce. The arrangement of these resources is our responsibility.

Family planning is not focusing to develop small families. Its scope is wider and applies to all. It provides the knowledge about reproductive health which is another sensitive issue. But it is very unfortunate that our college girl can talk about human digestive system, blood circulatory system and respiratory system etc. she however, hesitates to talk about reproductive system. People do not have any idea of the reproductive health and similarly they do not know what kind of sufferings they will get because of their lack of awareness of this particular issue. 


\section{Education}

When young people get more schooling, they acquire knowledge and skills that prepare them to gain practical knowledge which facilitates them in every aspect of their lives. This may be particularly relevant for younger women. A young lady, who is educated, may be able to get medical care more readily than her less educated peers and she may be more likely to take steps to maintain her reproductive health and the health of her family. This type of education should start after puberty, but we have no arrangements neither in school level nor in colleges to impart this knowledge. So we need to foster an attitude for establishing formal and informal reproductive health education at school, family and at community level. (Ali, Chaudhary Rehmat, 1987)

\section{Awareness}

About appropriate developmental stage for marriage. A young girl with a sense of awareness will be in a better position to decide about when and to whom she should marry. Early marriages among young women are universally associated with low levels of schooling. Adolescent age is not an appropriate developmental stage for marriage, whereas an early adulthood period is an ideal period to get marriage. In this stage she is

much better in taking decision to whom she is going to marry and how she will handle her marital life.

\section{Early Marriages}

In Islam there is no fixed time of marriage. It depends upon the social and economic status of individuals. Some religious people believes that start of puberty is the right time for marriage is due to the low level of education. But I feel maturity rather than puberty should be the criteria, for marriage. (Kazmi, (n.d))

\section{As Qur'an Indicates}

"And try orphans (as regards their intelligence) until they reach the age of marriage; if then you find sound judgment in them; release their property to them; but consume it not waste fully and hastily fearing that they should grew up". (Al-Quran, 4:46).

It is proved that physical maturity is less important than mental maturity. In many parts of the world like Pakistan's rural areas, a woman marries during her adolescent age, sometimes cutting short her education, in these conditions unplanned pregnancies for the unprepared young mother resulted, and many complications occur during the gestation period and at the delivery time. 


\section{Late Marriages}

It is also a common issue in our country and the basic reason of late marriage is unemployment because a man is usually expected to have achieved some measures of economic stability before he marries. Late marriages may result in serious consequences as abortion or some gynaecological problems during the birth of a child, as well as to the neonatal health.

\section{Allah Says \\ "Whatever of good reaches you, is from Allah, but whatever of evil befalls you, and is from yourself." (Al-Quran, 4:79)}

It is very clear that Allah has gifted us intelligence, so why do not we use it?

\section{Safe Motherhood}

For a healthy society we need healthy mother and a healthy child. Actually, the family planning program is based on healthy mother and healthy child. For mothers it deals with her reproductive health before marriage and after marriage and during pregnancies and after pregnancies. Although there is lack of consultation to a lady doctor for reproductive health before marriage. As we know that a larger portion of Pakistan's population is living below the poverty line and they are illiterate to, so there is an attitudinal lacking to think for the betterment of Pakistan in general. (Siddiqui, 1991)

\section{Child Bearing}

Usually young women have their first baby during the first year of marriage but the wishes of her family, the values of her culture, and the economic circumstances of her life are strongly influenced when she marries and begins child bearing. In this way she seeks to ensure the stability of her marriage and acquire status within her community. If mother is educated she can plan her family easily. First of all she has to take care of her reproductive health as well as general health.

\section{Upbringing of Child}

A responsibility of married couple now extends. They have to strive for child's health, education and moral and social training, but the first right of your child is breast feeding.

\section{Breast Feeding}

Breast feeding leads to child's nutrition as well as prevention of breast cancer. Every mother should breast feed her child necessarily. Allah has already arranged a natural interval between second pregnancies by the injunction of breast feeding for two years. 


\section{As Quran says}

"Mother shall give suck to their children for two whole years; for her who intends to sucking to be completed." (Al-Quran, 2:233)

During breast feeding child will be saved from diarrhea and other infectious diseases. Mother will recover her reproductive health after first delivery and she will be prepared for second pregnancy. Now it is the time after completion of two year of breast feeding she has to decide for her next pregnancy. Assure herself that her reproductive system is now healthy for child bearing after the consultation of lady doctor. If she has any transferable disease then she is advised to avoid pregnancy till she recovers. In this way automatically she will deliver her second child with good health. Healthy children will definitely built healthy nation after all.

\section{Delaying a Pregnancy}

How can a mother delay her pregnancy? Because breast feeding of a working women is very difficult and accuracy of this method is doubtful so she can use contraceptive. As women's level of education or awareness increases, she becomes more likely to obtain accurate information about health care and contraception and this is a better prepared position to plan her pregnancies.

\section{Contraceptive Methods and Reproductive Health}

Medical science guarantees that if a mother breast feeds to her child in appropriate way for six months, next pregnancy will be delayed definitely. If she wants to complete two years of breast feeding, she can use contraceptive method till the second child's desire. But their is a burning question what does Islam says about contraceptive method. At the beginning of Islam, companions of Hazrat Muhammad (Peace be upon him) narrated that during the revelation of Holy Quran we were doing the practice of coitus interrupts (AZL)." (Essa, (n.d))After the deep study of Ahadith it becomes clear that prophet has neither prohibited nor proposed "AZL". Similarly "AZL" was allowed under certain conditions, because of fanatic approach of religious leaders it became controversial, however if we don't get clear instruction in Quran and Sunnah we have a way of "logical" education from Quran and Sunnah by a council (Ijtihad). "AZL" was the only way for avoiding children at that time and by the passage of time when we are enjoying scientific inventions, why don't we use contraceptive methods in relation, and we can give up contraceptive methods when we come out of our problems mainly reproductive health problems or child's upbringing. (Rauf, 1979)

\section{Quran says}

"Allah intends for you ease and He does not want to make things difficult for you." (Al-Quran, 2:185) 
This verse makes it clear that Allah do not impose on you hardship.

\section{Permissibility of Contraceptive Methods}

A variety of contraceptive methods are available for individuals who wish to delay pregnancy. Throughout history, couples have relied upon traditional birth control methods such as periodic abstinence or withdrawal to prevent unwanted conceptions. This traditional method is not reliable and modern methods are more effective which are contraceptive pills, the hormonal implant, the inject able, the IUD barrier methods etc. all of these are temporary methods. Sterilization may be an option for both women and men. However because sterilization is a permanent form of birth control, it is rarely considered appropriate for young mothers and typically is issued by people who have had the number of children they want.

Islamic point of view about sterilization is that a method whereby either men or women resort minor surgery for compelling health reasons, so proper advice should be sought from a competent physician with due ethics. If physician determines that such a course of action is absolutely necessary to protect the person's life, then it is permissible. Always remember that liberty of a Muslim is bounded with some limitations. Physician must not cross the boundary line because Physician is the slave of Allah and his every step should be the will of Allah and according to the injunctions of Allah it is important that we try to understand the real will of Allah. It is compulsory to eliminate ignorance. Quran guides us in every condition with its rationality.

"He has forbidden you only the dead animals and blood and the flesh of swine and that which is slaughtered as a sacrifice for others than Allah. But if one is forced by necessity without wilful disobedience or transgressing due to limits then there is no sin on him. Truly Allah is forgiving, most Merciful." (2:173).

This verse shows that Allah's injunctions are flexible for individuals in some conditions. For reproductive health all contraceptive methods can be adopted after consultation of doctors. Here is very interesting report that while disapproving family planning program majority of religious scholars are convinced of contraceptive methods under certain conditions particularly health reasons, maternal mortality and infant mortality. Muslim jurists may deal with this situation by the door of Masaleh Mursala (Public Interest).

\section{Lack of Information}

Many young women do not have accurate or adequate information about reproductive health and contraceptive methods. Some chapters can be included in science and social 
studies in the syllabus at secondary school and Intermediate levels for male and female students.

\title{
Infectious Diseases
}

A young woman should know about those diseases which are dangerous for her health especially for her reproductive health. She may suffer from infections of the reproductive tract that can have a major impact on their ability to bear children. AIDS has become tragically common in many regions of the world, engulfing entire areas of that region leaving behind large numbers of orphaned children.

\begin{abstract}
Abortions
Abortion is sought only when the mother's life is in danger and by terminating unwanted pregnancy. Abortion is permissible as enshrined by Holy Quran in the following verses:

"We did create man from an essence of clay; then placed him a germ, in a safe enclosure. Then germ we made a clot of blood and the clot of lump offlesh. This we fashioned into bones then clothed the bones with flesh, and then produced it as another creation. Blessed be Allah the noblest of Creators." (Al-Quran, 23:12-14).
\end{abstract}

This means that after the seven stages are crossed. Allah blows the spirit into the foetus. If a woman seeks out an abortion having some genuine reasons as recommended by gynaecologist, before 120 days or before blowing spirit by Allah, it is permitted.

\section{Strategy to Promote Reproductive Health}

1. Equal preference should be given to both girls and boys education.

2. Marriage and child bearing should be in early adulthood.

3. Healthy attitudes should be promoted through workshops for reproductive health.

4. Young men also needs information about reproductive health, co-operation of a man is necessary for his life partner.

5. Parents must check and take time to guide their children about sexual attitude and behaviour. They need special attention and moral training.

\section{Quran says;}

"And let those who find not the financial means for marriage keep themselves chaste, until Allah enriches them of His Bounty." (Al-

Quran, 24:33).

From this verse we learn that, if a young man could not afford a wife, delay his marriage

until he struggle for affordable position. In the same manner when a couple have some 
problem, upbringing of their second child they delay his birth till favorable circumstances.

It has to be decided by that couple, because Quran has mentioned their status.

"They are garment for you and you are the same for them" (Al-Quran, 2:187)

In this manner both (husband and wife) have to protect themselves for every type of problems. They will mutually decide and plan for their family. It is because of their same status, another place Quran Says;

"And among his signs in this that He created for you wives from among yourselves that you may find repose in them and He has put between you affection and mercy verily, in that are indeed signs for a people who reflect." (Al- Quran, 30:21)

No doubt that peace lies in conjugal life, love and kindness. It is the couple's duty to make their life neat, disciplined and well planned. We observe so many stresses in life, like unemployment, poverty, street beggars, child labours, sexual harassment, illiteracy, prostitution, diseases, starvation and kidnapping etc. How can a couple enjoy their life?

"It is the duty of every couple especially every mother to deliver Healthy child and they are not supposed to focus on the number of child birth. The most honourable among you in the sight of Allah who is pious (who has Tqwa)." (Al- Quran, 49:13)

\section{Conclusion}

\section{Quran says;}

"Verily" Allah will not change the condition of a people as long as they do not change their state themselves." (Al-Quran, 13:11)

I would strongly advocate that health, finance, education, Women Development and Population Welfare Ministries support each other and adopt better informing policy. Lack of linkages creates misunderstanding and problems. It will be appropriate to involve local government councillors to educate people for their reproductive health rather than family planning. Some more strategies are:

- Establish Islamic Research Cells in all regional family welfare centres and in NGO's Invite Ulema on TV to talk about health and population issues along with a doctor who can convince them. 
- Organize seminars and workshops for women, educators and Religious Scholars specifically.

- Institutes of family planning arrange short courses on breast feeding, safe motherhood, upbringing of child, status of women, duties and men, duties of doctor and other professionals etc.

- Electronic Media and Print Media help to motivate and propagate these problems in Islamic context.

- Invite learned scholars to give their input in the form of articles or interviews. Introduce reproductive health as a subject and remove the misconception of family planning because it also deals with infertility and help out such couples.

- Large family size creates psychological and economic problems and unemployment so try to avoid it.

- In the same manner young people who are sexually abuse are obviously at risk of infections. They also suffer other trauma and psychological distress.

- Health and Family Planning program can be organized for religious leaders, particularly to reduce high risk birth and maternal deaths. We need to invite research scholars of different school of thoughts for "Ijtehad" and shut the door of controversies.

- Overcome the mismanagement of resource in every field.

In conclusion I would suggest that solution of our problems lies in the enforcement of Islamic values.

\section{As Quran demands;}

O you who believe enter perfectly in Islam. (Al- Quran, 2:208).

\section{References}

$\mathrm{Al}$ - Quran (6:59)

Al - Quran (47:24)

$\mathrm{Al}$ - Quran (51:56)

Al - Quran (2:229) 
Al - Quran (17:29)

Al - Quran (4:46)

Al - Quran (4:79)

Al - Quran (2:233)

Al - Quran (2:185)

Al - Quran (2:173)

Al - Quran (23:12-14)

Al - Quran (24:33)

Al - Quran (2:187)

Al - Quran (30:21)

Al - Quran (49:13)

Al - Quran (13:11)

Al - Quran (2:208)

Ali, Chaudhry Rehmat (1987) Women's Plight, Islamic Publications, Lahore, Pakistan.

Ess, Al-Tirmizi Muhammad Bin (n.d) Sunan Al-Tirmizi 'Bab al Azal' Dar Al Ahya Al Turas Al Arabi, Bairoot, Lebanon.

Kazmi, Shamim (n.d) Statistical Profile: Women of Sindh, Association of Business \& Professional Agriculture Women, Karachi, Pakistan.

Rauf, Muhammad Abdul (1979) The Islamic View of Women and the Family, Robert speller \& Sons, New York, USA.

Siddiqui, M. Mazaheruddin (1991) Women in Islam, New Taj Office, Delhi, India.

Dr. Shahnaz Ghazi is Assistant Professor in the Department of Qur'an \& Sunnah, University of Karachi. 